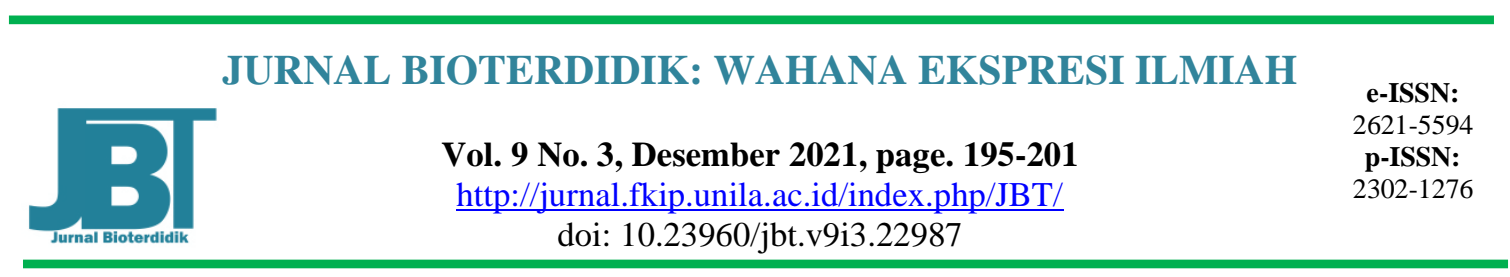

\title{
Perbandingan Metode Number Heads Together (NHT) Dan Metode Pembelajaran Student Team Achievement Division (STAD) Terhadap Hasil Belajar Siswa
}

\author{
Adha Apriana Siagian*, Kartika Manalu, Kahiruddin \\ *Tadris Biologi, Universitas Islam Negeri Sumatera Utara, Indonesia \\ *email: adhaapriana5@gmail.com
}

Received: November 11, 2021

Accepted: December 24, 2021

Online Publish: December 30, 2021

\begin{abstract}
Comparison methods Number Heads Together (NHT) and Student Team achievement Division (STAD) on student learning outcomes. This study aims to determine the differences between NHT) and STAD learning outcomes of clas VII Biology MTs Madinatussalam. The sample of this research is class VII-1 with 32 student as NHT class and 32 student in VII-2 as STAD class. The instrument used in this study was a multiple choice test concisting of 20 questions. The results of analysis showed that the average post-test score for the experimental class I NHT was 82 very high category. Meanwhile, the experimental class II STAD the average post-test score was 67,2 high category. The hypothesis test of the difference in learning outcomes of students in expremental class I NHT and expremental class II STAD, obtained tcount = 6,036>ttable $=1.999$, then $H_{o}$ is rejected and $H_{a}$ is acepted. This shows that there is a difference in the biology lerning out comes of student who are thought using NHT learning method and those taught using the STAD learning method.
\end{abstract}

Keywords: biology, NHT, result of study, STAD

Abstrak: Perbandingan Metode Number Heads Together (NHT) Dan Metode Pembelajaran Student Team Achievement Division (STAD) Terhadap Hasil Belajar Siswa. Penelitian ini bertujuan untuk mengetahui perbedaan model pembelajaran NHT dan model pembelajaran STAD terhadap hasil belajar biologi siswa kelas VII MTs di MTs Madinatussalam. Penelitian ini merupakan penelitian kuantitatif dengan jenis penelitian quasi eksperimen. Sampel penelitian ini adalah kelas VII-1 berumlah 32 orang sebagai kelas NHT dan VII-2 berjumlah 32 orang sebagai kelas STAD. Instrument yang digunakan dalam penelitian ini berupa tes pilihan ganda yang terdiri dari 20 soal. Hasil analisis data menunjukkan rata-rata nilai post-test kelas eksperimen I (NHT) adalah 82 (kategori sangat tinggi). Sedangkan pada kelas eksperimen II (STAD) diperoleh rata-rata nilai post-test sebesar 67,2 (kategori tinggi). Uji hipotesis perbedaan hasil belajar biologi siswa kelas eksperiment I dan eksprimen II, diperoleh $t_{\text {hitung }}=6,036$ $>\mathrm{t}_{\text {tabel }}=1,999$, maka $H_{0}$ ditolak dan $H_{a}$ diterima. Hal ini menunjukkan ada perbedaan hasil belajar biologi siswa yang diajar dengan menggunakan metode pembelajaran NHT dengan yang dijarkan menggunakan metode pembelajaran STAD.

Kata kunci: biologi, hasil belajar, NHT, STAD 


\section{PENDAHULUAN}

Pendidikan adalah usaha sadar untuk menyiapkan peserta didik melalui kegiatan bimbingan, pengajaran, atau latihan bagi peranannya di masa yang akan datang (UUR, 1. No 2 tahun 1989, Bab 1, Pasal 1). Pendidikan di Indonesia masih mengalami masalah terutama pada rendahnya mutu pendidikan. Indikasi pada masalah tersebut telah nampak dari beberapa kompetensi akademis dan kenyataan di masyarakat. Hal tersebut terlihat dari hasil penelitian tentang The Third International Mathematics and Science Study (TIMSS) yang diselenggarakan setiap empat tahun sekali, dimana Indonesia lima kali berpartisipasi dalam penelitian tersebut. Pertama, pada tahun 1999 dengan peserta 38 negara, Indonesia berada pada urutan ke-32 pada bidang sains. Kedua, pada tahun 2003, Indonesia berada urutan ke-35 dari 46 negara. Ketiga pada tahun 2007 dengan peserta 49 negara, Indonesia berada pada urutan ke-36 pada bidang sains. Keempat, pada tahun 2011 dengan peserta 42 negara, Indonesia berada pada urutan ke-38 pada bidang sains. Kelima, pada tahun 2015 dengan peserta 49 negara, Indonesia berada urutan ke-44 pada bidang sains (Harahap, 2014).

Pembelajaran adalah suatu proses timbal balik maupun kombinasi yang terjadi antara guru dengan siswanya pada saat belajar (Tanjung, 2020) atau suatu kombinasi yang tersusun meliputi unsur-unsr manusiawi, material, fasilitas, perlengkapan dan prosedur yang saling mempengaruhi mencapai tujuan pembelajaran. Manusia terlibat dalam sistem pengaaran terdiri dari siswa, guru dan tenaga lainnya, misalnya tenaga laboratorium (Trianto, 2012). Pembelajaran merupakan suat suatu system, yang terdiri atas berbagai komponen yang saling berhubungan erat dengan yang lain, yang mana komponen tersebut meliputi tujuan, materi, metode dan evaluasi (Rusman, 2012).

Pembelajaran Koopratif adalah rangkaian kegiatan belaar siswa dalam kelompok tertentu untuk mencapai tuuan pembelajaran yang dirumuskan. Ada empat unsur penting dalam pembelajaran koopratif yaitu adanya peserta dalam kelompok, adanya aturan dalam kelompok, adanya upaya belajar setiap anggota kelompok dan adanya tujuan yang harus di capai. Aturan kelompok adalah segala sesuatu yang menjadi kesepakatan semua pihak yang terlibat, baik siswa sebagai peserta didik, maupun siswa sebagai anggota kelompok. Misalnya, aturan tentang pembagian tugas setiap anggota kelompok, waktu dan tempat pelaksanaan, dan lain sebagainya (Tanjung, 2018).

Hasil belajar adalah seseorang setelah mereka menyelesaikan belajar dari sejumlah mata pelajaran dengan dibuktikan melalui hasil tes yang berbentuk nilai hasil belajar. Penyelesaian belaar ini bisa berbentuk hasil dalam satu sub pokok bahasan, maupun dalam beberapa pokok bahasan yang dilakukan dalam suatu test yang merupakan hasil dari usaha sungguh-sungguh untuk mencapai perubahan prestasi belajar siswa yang dilakukan dengan penuh tanggung jawab. hasil belajar adalah untuk kita dapat mengetahui dan memahami kemajuan peserta didiknya yang berasal dari dalam diri peserta didik itu sendiri yang mana dilatarbelakangi oleh pengetahuan dan kemampuan yang di miliki sendiri sehingga dapat berfungsi sebagai penambah informasi bagi peserta didik, orang tua, serta bagi badan bimbingan, penyuluhan dan semua orang.

Belajar adalah ditentukan oleh tujuan murid. Ia harus merasakan problema yang perlu dipecahkan (Asrul, 2015), belajar juga dapat dikatakan suatu tahapan perubahan tingkah laku yang melibatkan unsur kognitif, efektif dan psikomotorik (Jaya, 2019). Proses perubahan yang terjadi di dalam kepribadian manusia, dan perubahan tersebut terlihat dalam bentuk peningkatan kualitas dan kuantitas tingkah laku seperti peningkatan kecakapan, pengetahuan sikap, kebiasaan, pemahaman, keterampilan, daya 
pikir, dan kemampuan lain, serta peningkatan kualitas dan kantitas tingkah laku seseorang diperlihatkan dalam bentuk bertambahnya kualitas dan kuantitas kemampuan orang dalam berbagai bidang. Belajar tidak hanya terjadi di sekolah, dan tidak hanya terjadi ketika guru melakukan interaksi dengan murid serta tidak juga hanya pada saat seseorang sedang belajar menulis, membaca maupun berhitung. Melainkan belajar itu belajar itu bisa terjadi dalam semua aspek dari kehidupan kita (Syafaruddin, 2016). Jika di dalam suatu proses belajar seseorang mendapatkan suatu peningkatan kualitas dan kuantitas kemampuan, maka dapat dikatakan orang tersebut sebenarnya belum mengalami proses belajar mengaar atau dengan kata lain ia mengalami kegagalan di dalam proses belajar mengajar. Berhasil atau tidaknya seseorang dalam belajar tergantung kepada banyaknya faktor, antara lain: kondisi kesehatan, keadaan intelegensi dan bakat, keadaan, minat dan motivasi, cara belajar siswa keadaan keluarga dan lain sebagainya (Mardianto, 2016).

Pembelajaran kooperatif tipe Numbered Headss Together (NHT) adalah strategi pembelajaran yang mengedepankan aktivitas siswa dalam mencari, mengelola dan melaporkan informasi dari beberapa sumber belajar untuk dipresentasikan di depan kelas. Atau pendekatan yang dikembangkan untuk melibatkan banyak sisiwa dalam reviu berbagai materi yang dibahas dalam sebuah pelajaran untuk memeriksa pemahaman siswa tentang isi pelajaran (Kawuwung, 2019).

Student Teams Achievement Division (STAD) adalah salah satu tipe metode pembelajaran koopratif yang menempatkan siswa dalam tim yang beranggotakan kurang lebih 4 orang yang merupak campuran menurut tingkat prestasi, jenis kelamin, dan suku. Yang mana komponen utama dalam metode STAD terdiri dari penyaian kelas, penetapan siswa dalam kelompok, tes dan kuis, skor pengembangan dan penhargaan kelompok (Murtiani, 2019).

Materi pembelajaran adalah segala sesuatu yang menadi isi kurikulum yang harus dikuasai siswa sesuuai dengan kompetensi dasar dalam rangka pencapaian standar kompetensi setiap mata pelajaran dan satuan pendidikan tertentu, isi atau contect yang harus di pelajari dan dikuasai siswa (Ananda, 2019).

Menurut UU RI Nomor 23 Tahun 1997 pencemaran lingkungan adalah masuknya atau dimasukkannya mahluk hidup, zat, energi, atau komponen lain ke dalam lingkungan hidup oleh kegiatan manusia sehingga kalitasnya turun sampai ke tingkat tertent yang menyebabkan lingkungan hidup tidak dapat berfungsi sesuai dengan peruntukannya. Jadi pencemaran lingkungan terjadi akibat kumpulan kegiatan manusia (populasi) dan bukan dari kegiatan perorangan (Individu). Sebagaimana di jelaskan dalam Al-Qur'an surah Ar-Rum: 41, yaitu:

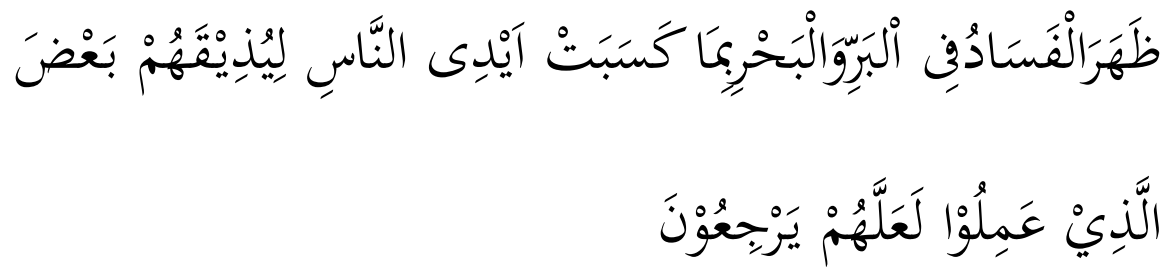

Artinya:

"Telah tampak kerusakan di darat dan di laut disebabkan perbuatan tangan manusia, Allah menghendaki agar mereka merasakan sebagian dari akibat perbuatan mereka, agar mereka kembali ke jalan yang benar)". Ar-rum[30]:41

\section{METODE}


Penelitian ini dilaksanakan di MTs Madinatussalam kota Medan Kab. Deli Serdang pada kelas VII semester genap Tahun Pelajaran 2020/2021 yang beralamat di Jalan Sidomulyo Pasar IX Gg Pipit Dusun XIII, Kec. Percut Sei Tuan, Kab Deli Serdang Prov. Sumatera Utara. Waktu peneitian dimulai dari bulan Januari sampai dengan bulan Februari 2021. Populasi dalam penelitian ini adalah sebagian kelas VII MTs Madinatussalam yang berjumlah 97 orang yang terbagi ke dalam 3 kelas yaitu kelas VII-1 terdiri dari 32 siswa, kelas VII-2 terdiri dari 32 siswa dan kelas VII-3 terdiri dari 33 siswa. Sample yang digunakan dalam penelitian ini adalah sebagian anggota populasi target terdiri dari dua kelas yang ditentukan secara cluster random sampling (sample acak berkelompok). Untuk menentukan jenis perlakuan pada masing-masing kelas tersebut dilakukan dengan pertimbangan-pertimbangan sehingga diproleh kelas VII-1 yang beranggotakan 32 Siswa sebagai kelas eksprimen I yang diajarkan dengan metode pembelajaran koopratif tipe Number Heads Together (NHT), kelas VII-2 yang beranggotakan 32 Siswa sebagai kelas eksprimen II yang diajarkan dengan metode pembelajaran koopratif tipe Student Teams Achievement Division (STAD).

Jenis penelitian ini adalah quasi eksperimen dengan pendekatan kuantitatif desain yang digunakan dalama penelitian ini adalah posttest only control design dengan dua kelompok perlakuan berbeda. Kelompok pertama sebagai kelompok eksperimen I yang diajar dengan motode pembelajaran Number Heads Together (NHT) dan kelompok II yang diajar dengan metode pembelajaran. Student Team Achievement Division (STAD). Desain penelitian ini dapat dilihat sebagai berikut:

Tabel 1. Desain Penelitian

\begin{tabular}{|c|c|c|c|c|}
\hline & Kelompok & Perlakuan & Pre-test & Post-test \\
\hline & Eksperimen & $\mathrm{X}$ & $\mathrm{O}_{1}$ & $\mathrm{XO}_{1}$ \\
\hline & Kontrol & Y & $\mathrm{O}_{2}$ & $\mathrm{XO}_{2}$ \\
\hline \multicolumn{5}{|c|}{ Keterangan: } \\
\hline $\mathrm{X}$ & \multicolumn{4}{|c|}{ : Kelas dengan menggunakan NHT } \\
\hline $\mathrm{Y}$ & \multicolumn{4}{|c|}{ : Kelas dengan menggunakan STAD } \\
\hline $\mathrm{O}_{1}$ & \multicolumn{4}{|c|}{ Pretest diawal kelas NHT } \\
\hline $\mathrm{O}_{2}$ & \multicolumn{4}{|c|}{ : Pretest diawal kelas STAD } \\
\hline $\mathrm{XO}_{1}$ & \multicolumn{4}{|c|}{ : Posttest diakhir kelas NHT } \\
\hline $\mathrm{XO}_{2}$ & \multicolumn{4}{|c|}{ Posttest diakhir kelas STAD } \\
\hline
\end{tabular}

Instrument yang digunakan dalam penelitian untuk mengukur hasil belajar kognitif siswa pada materi pencemaran lingkungan adalah tes hasil belajar berupa pilihan ganda berjumlah 20 item yang diberikan sebelum dan sesudah perlakuan. Adapun langkah-langkah teknik validasi instrument dalam penelitian sebagai berikut: (1) Uji Validitas Tes; (2) Reliabilitas Tes; (3) Taraf Kesukaran Tes; (4) Daya Pembeda Tes. Teknik analisis data berupa analisis deskriptif dan analisis infrensial (Normalitas, Homogenitas dan Hipotesis).

\section{HASIL DAN PEMBAHASAN}

Dalam penelitian ini, untuk mengetahui perbandingan hasil belajar biologi siswa yang diajar menggunakan NHT dan yang diajar menggunakan STAD. Nilai hasil belajar pada pretest dan posttest terdapat perbedaan hasil belajar pada tiap kelas. Pada kelas 
yang diperlakukan dengan NHT memiliki rata-rata lebih tinggi dibandingkan kelas STAD. Deskripsi hasil pretest dan posttest dapat dilihat pada tabel 2.

Tabel 2. Deskripsi Hasil Pretest dan Posttest

\begin{tabular}{cccc}
\hline No Hasil Belajar & \multicolumn{2}{c}{ Kelas } \\
\cline { 3 - 4 } & & $\begin{array}{c}\text { Eksperimen Number } \\
\text { Heads Together } \\
\end{array}$ & $\begin{array}{c}\text { Eksperimen } \\
\text { Student Team } \\
\text { Achievement } \\
\text { Nivision } \text { (STAD) }\end{array}$ \\
\hline $\mathbf{1}$ & Pretest & 36,09 & 37,26 \\
\hline $\mathbf{2}$ & Posttest & 82,03 & 67,17 \\
\hline
\end{tabular}

Pengujian normalitas pertama dilakukan pada kelas Number Heads Together (NHT). Taraf signifikasi yang ditetapkan sebelumnya adalah 0,05 dan derajat kebebasan $=\mathrm{k}-1$ (dk). Ditemukan nilai statistik kolmogorov smirnov berupa nilai deviasi maksimum (Dhitung) $=0,226$. Nilai tersebut selanjutnya dibandingkan dengan nilai kolmogorov smirnov ( $\mathrm{D}_{\text {tabel }}$ ). Jika $\mathrm{N}=32$ dan taraf signifikasi 0,05, maka nilai kolmogorov smirnov $=0,234$. Karena nilai $D_{\text {hitung }}$ lebih kecil dari nilai $D_{\text {tabel }}$ $(0,226<0,234)$, maka data berdistribusi normal.

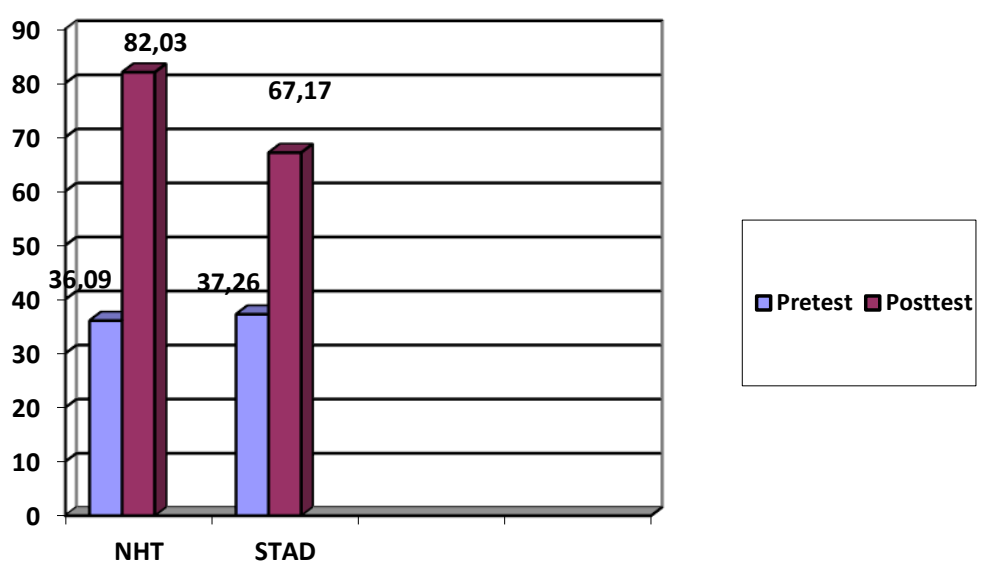

Gambar 1. Histogram rata-rata nilai

Pengujian normalitas kedua dilakukan pada hasil pretest dan post-test kelas Student Team Achievement Division (STAD). Taraf signifikasi yang ditetapkan sebelumnya adalah 0,05 dengan $\mathrm{N}=30$. Hasil pengujian ditemukan nilai statistik kolmogorov smirnov berupa nilai deviasi maksimum $\left(\mathrm{D}_{\text {hitung }}\right)=0,188$. Nilai tersebut selanjutnya dibandingkan dengan nilai tabel kolmogorov smirnov ( $\mathrm{D}_{\text {tabel }}$ ). Jika $\mathrm{N}=32$ dan taraf signifikasi 0,05 , maka nilai tabel kolmogorov smirnov $=0,234$. Karena nilai $D_{\text {hitung }}$ lebih kecil dari nilai $\mathrm{D}_{\text {tabel }}(0,188<0,234)$, maka data berdistribusi normal.

Dan pada kelas Student Team Achievement Division (STAD)ditemukan nilai statistik kolmogorov smirnov berupa nilai deviasi maksimum $\left(\mathrm{D}_{\text {hitung }}\right)=0,205$. Nilai tersebut selanjutnya dibandingkan dengan nilai kolmogorov smirnov ( $\left.\mathrm{D}_{\text {tabel }}\right)$. Jika $\mathrm{N}=32$ dan taraf signifikasi 0,05 , maka nilai kolmogorov smirnov $=0,234$. Karena nilai $\mathrm{D}_{\text {hitung }}$ lebih kecil dari nilai $\mathrm{D}_{\text {tabel }}(0,205<0,234)$, maka data berdistribusi normal. 
Sebelum mengadakan pengujian hipotesis, maka terlebih dahulu dilakukan uji homogenitas. Karena hal ini merupakan pengujian dalam analisis inferensial. Uji homogenitas bertujuan untuk melihat apakah data pada kedua kelompok berasala dari populasi yang homogen. Adapun hipotesis untuk uji homogenitas adalah sebagai berikut:

$\mathrm{H}_{0}=$ Populasi homogen, jika $\mathrm{F}_{\text {hitung }} \leq \mathrm{F}_{\text {tabel }}$

$\mathrm{H}_{\mathrm{a}}=$ Populasi tidak homogen, jika $\mathrm{F}_{\text {hitung }} \geq \mathrm{F}_{\text {tabel }}$

Untuk melakukan perhitungan pada uji homogenitas, maka digunakan uji $\mathrm{F}$ dengan rumus sebagai berikut:

$$
\mathrm{F}_{\text {hitung }}=\frac{\text { varians terbesar }}{\text { varians terkecil }}
$$

Perhitungan dilakukan secara manual menggunakan Microsoft Excel, dan diperoleh

data-data sebagai berikut:

a Nilai varians kelas NHT $=46,547$

b Nilai varians kelas STAD $=65,701$

Sehingga diperoleh nilai dari uji $F_{\text {hitung }}=1,090$. Sedangkan untuk $F_{\text {tabel }}=1,822$ dengan derajat kebebasan $(\mathrm{dk})=62$, dan taraf signifikasi 0,05. Dengan demikian $F_{\text {hitung }}$ $\leq \mathrm{F}_{\text {tabel }}=1,09 \geq 1,82$ maka dapat disimpulkan bahwa kedua kelompok data bersifat homogen.

Uji hipotesis dilakukan untuk mengetahui apakah hasil belajar siswa pada kelompok NHT berbeda secara signifikan dengan hasil belajar siswa pada kelompok STAD. Dengan demikian dirumuskan hipotesis statistilk sebagai berikut:

Hipotesis Nihil $\left(\mathrm{H}_{0}\right)=$ tidak ada perbedaan, nilai Sign hitung $\leq \alpha(0,05)$

Hipotesis alternatif $\left(\mathrm{H}_{\mathrm{a}}\right)=$ ada perbedaan, nilai Sign hitung $\geq \alpha(0,05$, dengan kriteria pengujian adalah jika nilai Sign hitung $\geq \alpha\left(0,05\right.$ maka $\mathrm{H}_{\mathrm{a}}$ diterima dan $\mathrm{H}_{0}$ ditolak, berarti ada perbedaan hasil belajar biologi siswa antara kelas eksperimen I(VII-1) dengan kelas eksperimen II (VII-2).

Pengujian hipotesis yang digunakan dalam penelitian ini yaitu uji t-test. Perhitungan dilakukan secara manual dengan Microsoft Excel 2010 dan didapatkan data seperti dalam Tabel 3.

Tabel 3. Uji Hipotesis (Uji t-Test)

\begin{tabular}{|c|c|c|}
\hline Statistik & NHT & STAD \\
\hline Rata-Rata & 82,1 & 67,2 \\
\hline $\begin{array}{c}\text { Simpangan } \\
\text { Baku }\end{array}$ & 1,17 & 1,39 \\
\hline Varians & 46,55 & 71,87 \\
\hline $\begin{array}{c}\text { Derajat } \\
\text { Kebebasan }\end{array}$ & \multicolumn{2}{|c|}{62} \\
\hline $\begin{array}{l}\text { Koefisien } \\
\text { Korelasi }\end{array}$ & \multicolumn{2}{|c|}{0,19} \\
\hline thitung $_{\text {hith }}$ & \multicolumn{2}{|c|}{6,036} \\
\hline ttabel & \multicolumn{2}{|c|}{1,999} \\
\hline
\end{tabular}

Hasil analisis data menunjukkan rata-rata nilai pretest pada kelas eksperimen I (NHT) adalah 36,1. Rata-rata hasil belajar pada kelas eksperimen I sebelum diajar menggunakan metode pembelajaran NHT ini dikategorikan rendah. Rata-rata nilai 
posttest kelas eksperimen I setelah diajar dengan menggunakan metode pembelajaran NHT adalah 82,03 sehingga masuk ke dalam kategori sangat tinggi. Sedangkan pada kelas eksperimen II (STAD), diperoleh rata-rata nilai pretest sebesar 37,26 (kategori rendah), dan nilai posttest sebesar 67,2 masuk ke dalam kategori tinggi.

Pada uji hipotesis perbedaan antara nilai post-test kelas eksperimen I dan eksperimen II, diperoleh $t_{\text {hitung }}=6,036>t_{\text {tabel }}=1,999$, pada taraf $\alpha=0,05$ maka $H_{0}$ ditolak dan $H_{a}$ diterima. Hal tersebut menunjukkan bahwa terdapat perbedaan yang berarti antara kelas eksperimen I (VII-1) dengan penggunaan metode pembelajaran NHT dan kelas eksperimen II (VII-2) dengan penggunaan metode pembelajaran STAD. Oleh karena itu, ada perbedaan yang signifikan dengan digunakannya metode pembelajaran NHT dan STAD terhadap hasil belajar biologi siswa.

\section{SIMPULAN}

Berdasarkan hasil belajar siswa yang diajarkan dengan NHT dan STAD diperoleh $t_{\text {hitung }}=6,036>t_{\text {tabel }}=1,999$ dengan taraf nyata $\alpha=0,05 \mathrm{dan} \mathrm{dk}=62$. Hal ini menunjukkan bahwa $\mathrm{H}_{0}$ ditolak dan $\mathrm{H}_{\mathrm{a}}$ diterima, sehingga dapat disimpulkan bahwa ada perbedaan hasil belajar biologi siswa yang diajar menggunakan metode pembelajaran NHT dengan yang diajar menggunakan metode pembelajaran STAD.

\section{DAFTAR RUJUKAN}

Al-Quran dan Terjemahannya. (2015). Jakarta: Depertemen Agama Republik Indonesia Ananda, R. (2019). Perencanaan Pembelajaraan, Medan : LPPI

Asrul. (2015). Evaluasi Pembelajaran. Medan: Perdana Mulya Sarana.

Jaya, F. (2019). Perencanaan Pembelajaran. Medan: FITK UINSU.

Harahap, N. (2014). Hubungan antara Motivasi dan Aktivitas Belajar Siswa Terhadap Hasil Belajar Kognitif siswa dengan Penerapan Model Pembelajaran Koopratif Tipe Student Teams Achievement Division pada Konsep Ekosistem. Visipena Jurnal, 5(1), 35-46.

Jaya, Indra, \& Ardat. (2013). Penerapan Statistik Untuk Pendidikan. Medan: Citapustaka Media Perintis.

Mardianto. (2016). Psikologi Pendidikan. Medan: Perdana Publishing.

Murtiani, Lestari, \& Irwandi. (2019). Penerapan Model Pembelajaran Student Team Achievement Divisions (STAD) dan Number Head Together (NHT) terhadap Hasil Belajar Siswa. Diklabio, 3(2).

Rusman. (2012). Model-Model Pembelaaran. Jakarta: Raja Graindo Persada.

Syafaruddin, Asrul, \& Mesiono. (2016). Inovasi Pendidikan: Suatu Analisis terhadap Kebijakan Baru Pendidikan. Medan: Perdana Publishing.

Tanjung, I. (2018). Strategi Pembelajaran Biologi. Medan: Widya Puspita.

Tanjung, dkk. (2020). Pengaruh Strategi Pembelajaraan Discovery Learning Berbantuan

Mini-Magz Terhadap Hasil Belajar Kognitif Biologi Siswa. Jurnal Biolokus, 3(2).

Trianto. (2012). Model Pembelajaran Terpadu, Jakarta: Bumi Aksara. 